\title{
A innovative use of discarded intravenous fluid bottle: as arterial cover
}

Tanmay Tiwari, , Harsh Vardhan and Yogesh Kumar Manik

*Correspondence: tanmayanesthesia@gmail.com

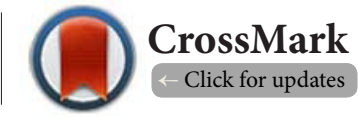

Tanmay Tiwari, LLRM Medical College, Uttar Pradesh, India.

\section{Correspondence}

In the present era of anesthesia and critical care the use of indwelling arterial catheters have a significant role for continuous haemodynamic monitoring both in the operating room and in critically ill patients in ICU. Arterial cannulation provides easy and convenient access, allowing multiple blood samplings, blood gas analysis and cardiac output measurements in patients with cardiovascular diseases undergoing surgeries which involve major fluid shifts, significant blood loss and autonomic disturbances. Yet, arterial cannulations are not without problems and complications. Accidental intraarterial (IA) injections of IV substances used during anesthesia can result in significant morbidity secondary to local ischemia and subsequent tissue necrosis. Case reports and incidences of iatrogenic intra-arterial (IA) injection of medications have been published since the 1940's [1-3].

With unintentional IA injection, both acute and chronic manifestations can be expected. Many patients complain of immediate discomfort, ranging from local irritation to intense pain distal to the site of injection [4-8]. Because pain is often the initial symptom, patients who cannot report discomfort are often subjected to an increased Intraarterial dose of medication. This may result in an increased likelihood of severe adverse sequelae. Such patients include those who are undergoing general anesthesia, receiving mechanical ventilation, comatose or have altered mental status, mentally handicapped, of the pediatric population, and trauma victims with distracting injuries. In a setting in which a medication needs to be administered urgently or emergently, it is easy to envision how a medication could be injected through a port of an arterial line.

Here we report a simple and indigenous way of securing the arterial line(arterial cover) with the help of used bottle of intravenous fluids so that they stand apart from the rest of peripheral lines and alert the care giver about the presence of the indwelling arterial catheter in the extremity and avoid accidental intrarterial injections and thereby preventing serious complications (Figure 1). The use of arterial cover also provides an added advantage of preventing the dampening of arterial waveform due to position change and pressure from

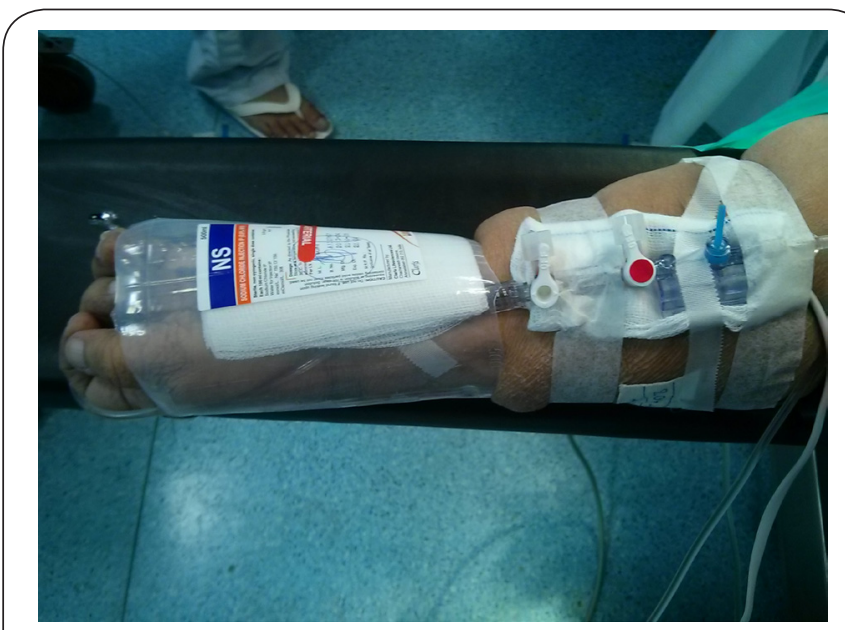

Figure 1. A simple and indigenous way of securing the arterial cover with the help of used bottle of intravenous fluids.

operating surgeons. As used plastic bottles of intravenous fluids is readily available both in operating rooms and in ICU, the above mentioned idea is less time consuming and does not incur any extra cost on patients budget.

Competing interests

The authors declare that they have no competing interests.

Authors' contributions

\begin{tabular}{|l|c|c|l|}
\hline Authors' contributions & TT & HV & YKM \\
\hline Research concept and design & $\checkmark$ & -- & -- \\
\hline Collection and/or assembly of data & $\checkmark$ & -- & -- \\
\hline Data analysis and interpretation & $\checkmark$ & -- & -- \\
\hline Writing the article & $\checkmark$ & -- & -- \\
\hline Critical revision of the article & $\checkmark$ & -- & -- \\
\hline Final approval of article & $\checkmark$ & $\checkmark$ & $\checkmark$ \\
\hline
\end{tabular}

Publication history

EIC: D. John Doyle, Case Western Reserve University, USA.

Received: 27-May-2014 Final Revised: 07-Jul-2014

Accepted: 10-Jul-2014 Published: 15-Jul-2014 


\section{References}

1. Lundy JS. Philadelphia, Pa: WB Saunders Co. Clinical Anaesthesia. 1942; 542.

2. Van der Post $\mathrm{CH}$. Report of a case of mistaken injection of pentothal sodium into an aberrant ulnar artery. S Afr Med J. 1942; 16:182.

3. Macintosh RR, Heyworth PA. Intra-arterial injection of pentothal. Lancet. 1943; 2:571.

4. Gould JD and Lingam S. Hazards of intra-arterial diazepam. Br Med J. 1977; 2:298-9. | Article | PubMed Abstract | PubMed Full Text

5. Doppman JL, Albertson K, Ramsey R and Saltzstein SL. Intra-arterial valium: its safety and effectiveness. Radiology. 1973; 106:335-8. | Article I PubMed

6. Klatte EC, Brooks AL and Rhamy RK. Toxicity of intra-arterial barbiturates and tranquilizing drugs. Radiology. 1969; 92:700-4. | Article | PubMed

7. Schulenburg CE, Robbs JV and Rubin J. Intra-arterial diazepam. A report of 2 cases. S Afr Med J. 1985; 68:891-2. I PubMed

8. Schneider $S$ and Mace JW. Loss of limb following intravenous diazepam. Pediatrics. 1974; 53:112-4. | PubMed

\section{Citation:}

Tiwari T, Vardhan H and Kumar Manik Y. A innovative use of discarded intravenous fluid bottle: as arterial cover. J Anesthesiol Clin Sci. 2014; 3:6.

http://dx.doi.org/10.7243/2049-9752-3-6 